\title{
NUTRICIONAL ASSESSMENT OF INGREDIENTS USED IN PACIFIC WHITE SHRIMP FEED ${ }^{1}$
}

\author{
CESAR ANTUNES ROCHA NUNES ${ }^{2 *}$, MARIA DO CARMO MOHAUPT MARQUES LUDKE ${ }^{3}$, CLOVIS MATHEUS $^{2}$ \\ PEREIRA $^{4}$, MISLENI RICARTE DE LIMA ${ }^{5}$, JOSÉ DOS SANTOS ${ }^{6}$
}

\begin{abstract}
Studies on feeding and nutrition of shrimp are still quite scarce; little is known about the use of agribusiness byproducts in shrimp diets. Therefore, this study aimed to perform nutritional and energy assessments of protein-based ingredients for feed of shrimp of the Litopenaeus vannamei species. The design was completely randomized, with six treatments and four replications: a standard diet and five test diets composed of $70 \%$ standard diet and 30\% test ingredients (poultry viscera flour - PVF, cassava leaf hay - CLH, shrimp head flour - SHF, sugarcane yeast - SCY and castor bean meal - CBM). We used a total of 720 shrimps with mean weight of $8 \mathrm{~g}$ each. The parameters of quality showed no significant change by the Tukey's test ( $\mathrm{p}>$ 0.05). The apparent digestibility coefficients of PVF, CLH, SHF, SCY and CBM were respectively 27.44, $76.26,77.78$ and $90.10 \%$ for dry matter; $76.61,70.44,97.67$ and $78.29 \%$ for protein; and $33.10,51.19,90.70$ and $78.05 \%$ for gross energy. The digestible energy of the ingredients was 1749, 2457, 3914, 3030 and 2130 $\mathrm{kcal} / \mathrm{kg}$; and digestible protein was 42.4, 16.09, 54.62, 23.71 and 14.31\%. The SHF reached the highest coefficients of apparent digestibility, crude protein, gross energy and digestible energy. The SCY had the largest apparent digestibility of dry matter. Both SHF and SCY presented improved availability of nutrients and energy for L. vannamei.
\end{abstract}

Keywords: Alternative food. Digestible energy. Litopenaeus vannamei.

\section{AVALIAÇÃO NUTRICIONAL DE INGREDIENTES PARA O CAMARÃO BRANCO DO PACÍFICO}

RESUMO - Os estudos sobre alimentação e nutrição de camarões ainda são muito escassos, pouco se sabe sobre o aproveitamento pelos camarões de subprodutos da agroindústria, portanto o objetivo deste trabalho foi à avaliação nutricional e energética de ingredientes proteicos para camarões (Litopenaeus vannamei). $\mathrm{O}$ delineamento foi inteiramente casualizado, com seis tratamentos e quatro repetições: uma Reference diete cinco dietas teste compostas de $70 \%$ da Reference diete $30 \%$ do ingrediente teste (farinha vísceras de aves-FVA, feno folha de mandioca- FFM, farinha cabeça de camarão-FCC, levedura de cana-de-açúcar-LC e farelo de mamona -FM). Utilizou-se 720 camarões com peso médio de $8 \mathrm{~g}$. Os parâmetros de qualidade não apresentaram diferença significativa pelo teste de Tukey $(\mathrm{P}>0,05)$. Os coeficientes de digestibilidade aparente dos ingredientes FVA, FFM, FCC, LC e FM foram respectivamente, 27,44; 76,26; 77,78 e 90,10\% para matéria seca;76,61; 70,44; 97,67 e 78,29\% para proteína e $(33,10 ; 51,19 ; 90,70$ e 78,05\%) para energia bruta. A energia digestível dos ingredientes foi $1.749,2.457,3.914,3.030$ e $2.130 \mathrm{kcal} / \mathrm{kg}$ e proteína digestível foi de 42,4 ; 16,09; 54,62, 23,71 e 14,31\%. A FCC apresentou os maiores coeficientes de digestibilidade aparente da proteina bruta e energia bruta e para energia digestível. A LC apresentou o maior valor do coeficiente de digestibilidade aparente da matéria seca. A FCC e a LC são os ingredientes que apresentaram os melhores aproveitamentos dos nutrientes e da energia para L. vannamei.

Palavras-chave: Alimentos alternativos. Energia Digestível. Litopenaeus vannamei.

\footnotetext{
*Corresponding author

${ }^{1}$ Received for publishing in 10/28/2014; accepted in 02/16/2016.

Paper extracted from the doctoral thesis of the first author.

${ }^{2}$ Department of Human Sciences and Technology, Universidade do Estado da Bahia, Xique-Xique, BA, Brazil; cesar@zotecnista.com.br.

${ }^{3}$ Department of Animal Science, Universidade Federal Rural de Pernambuco, Recife, PE, Brazil; mohauptmariadocarmo@gmail.com.

${ }^{4}$ Research Center of Agricultural, Environmental and Biological Sciences, Universidade Federal do Recôncavo da Bahia, Cruz das Almas, BA, Brazil; clovismatheuspereira@hotmail.com.

${ }^{5}$ Department of Animal Science, Universidade Federal Rural do Semi-Árido, Mossoró, RN, Brazil; misleniricarte@hotmail.com

${ }^{6}$ Technical-vocational course in Aquaculture, Instituto Federal Baiano, Valença, BA, Brazil; josepescadorufrb@hotmail.com.
} 


\section{INTRODUCTION}

The main species of marine shrimp commercially produced worldwide is the Litopenaeus vannamei (DASTIDAR; MALLIK; MANDAL, 2013). This species is typically euryhaline and has the ability to withstand wide ranges of salinity $(0.5-40 \mathrm{~g} / \mathrm{L})$, which prompted its cultivation in olygohaline waters (HAVIRD; SANTOS; HENRY, 2014).

Shrimp marine species farming may be feasible in inland waters of low salinity which are unsuitable for conventional agriculture, becoming an alternative to reduce costs and enable shrimp farming in areas of low agricultural production (PRAPAIWONG; BOYD, 2014).

Alternative ingredients can replace conventional protein foods used in feed of aquatic organisms, which occurs largely due to the high cost of these ingredients, since feeding expends about 60 to $70 \%$ of the production costs (CUMMINS et al., 2013).

A higher coefficient of digestibility of certain ingredients might have economic effect by increasing the feeding efficiency, influencing the performance and quality of water through waste reduction in farming environments (GHUO et al., 2006). The low digestibility of food leads to accumulation of residues in soil and water, making the environment hypereutrophic and of low quality, causing diseases to animals (LIN et al., 2006).

By knowing the digestibility of alternative ingredients, we can reduce costs in feed formulation; however, maintaining a formula that still fulfill the nutritional requirements of animals (BUGLIONE-NETO et al., 2013).

Protein-based food represents the highest percentage of costs in feed formulation for aquatic animals because of the large amount required and due to their higher costs in diets (LEMOS; LAWRENCE; SICCARDI III, 2009).

The ingredients currently used as protein source in aquaculture can be replaced, in part or full, by other alternatives, such as soy meal. However, it is extremely important to perform studies on the digestibility level of such ingredients to optimize shrimp nutrient uptake.

Alternative ingredients originating from the agricultural industry can be critical for the maintenance and growth of production and consequent food cost reduction for aquatic animals.

Poultry viscera flour is a byproduct of slaughtering industry and can be used in monogastric animal feed manufacturing. This residue appears as a protein alternative food for aquatic organisms, since it is widely available and has high nutritional value. The crude protein content ranges from 55 to $65 \%$ with apparent digestibility coefficient between $78.7 \%$ and $90.4 \%$, found in experiments with $L$. vannamei (CRUZ-SUÁREZ et al., 2007).

Cassava (Manihot esculenta Crantz) is a widespread crop worldwide, and is one of the main sources of energy for human nutrition in tropical countries (DA; LUNDH; LINDBERG, 2012). Its leaves are considered a byproduct from root harvesting and, in most cases, wasted in all regions. According to a study of Ramos et al. (2012), cassava shoot dry matter makes $92.7 \%$ of the total biomass, with a total crude protein of $21.9 \%$ and gross energy of $19.5 \mathrm{MJ} / \mathrm{kg}$. Even though little used to feed aquatic organisms, whole hay of cassava leaves could be an important ingredient to reduce feeding costs.

Shrimp production and processing generate solid waste, consisting of large amounts of shrimp head and shell, which correspond to approximately $40 \%$ of total produced weight, being then discarded at the end of the processing (ASSIS; STAMFORD; STAMFORD, 2008). Shrimp meal can be a good form of exploitation of this remaining material, bringing economic and environmental benefits. Its nutritional composition is rich and has a crude protein rate of $60.6 \%$ (LIMA et al., 2007), besides of essential amino acids (BHASKAR et al., 2010), which is quite close to fishmeal.

Another important ingredient, mainly in northeastern Brazil, is the sugarcane yeast (Saccharomyces cerevisiae). It is a byproduct from ethanol industry, in which Brazil is emerging as the world's largest producer. Moreover, it consists of a feasible alternative for aquatic animal diets, since it has good nutritional characteristics, such as crude protein levels ranging from 22.41 to $40.18 \%$ with good balance of essential amino acids, particularly lysine (POVEDA-PARRA et al., 2013). According Hisano et al. (2008), whole yeast has a high protein content and good digestibility of nutrients and amino acids.

Eventually, castor bean (Ricinus communis L.), which is well adapted to high temperatures, easy handling and low production cost. Furthermore, according to Mota and Pestana (2011), there is a great potential for the use of agro-industrial waste of castor bean in animal feeding, since its detoxified bran shows a percentage of dry matter of $95.25 \%$, crude protein of $39.82 \%$, crude fiber of $28.48 \%$, ether extract of $1.58 \%$, mineral material of $6.31 \%$, and nitrogen free extract of $23.81 \%$. This ingredient quality and the social background, where such raw material production is inserted, are important requirements for the choice of ingredients that will be used in shrimp feed manufacturing.

Therefore, the aim of this study was to determine the nutritional and energy value of the protein-based ingredients: poultry viscera flour, cassava leaf hay, shrimp head flour, sugarcane yeast and castor bean meal for Pacific white shrimp. 


\section{MATERIAL AND METHODS}

Evaluations were carried out at an experimental area of the Research Center for Fisheries Resources and Aquaculture (NEPA) of the Universidade Federal do Recôncavo da Bahia UFRB (Federal University of Bahia Recôncavo UFRB), from December of 2011 to March of 2012. We used a total of 720 shrimps of the L. vannamei species with an average weight of $8 \mathrm{~g}$, which were provided by the Oruabo Experimental Farm - Bahia Pesca SA, located in Santo Amaro, Bahia, Brazil.

The experiment was accomplished in a completely randomized design with a standard diet and five treatments with four replications. Preliminarily, shrimps were acclimatized for 21 days at salinity of $0.8 \mathrm{~g} / \mathrm{L}$ in fiberglass tanks with 1,500 liters.

Water quality variables were measured at a daily basis $(\mathrm{pH}$, dissolved oxygen, temperature, salinity and conductivity), using a multiparameter probe (HANNA HI 9828). Weekly, total alkalinity was measured by titration method described by Golterman, Clymo and Ohnstad (1978), at the Water Quality laboratory of the UFRB. Yet the degree of water hardness was made with the Dureza Total GH kit; and the ammonia content was measured using Amônia Tóxica kit of the LabconTest ${ }^{\circledR}$.

Daily, $80 \%$ of the water from 1,500-L polyethylene tanks was renewed by public network supply together with seawater, until reach a salinity level of $0.8 \mathrm{~g} / \mathrm{L}$. After mixing fresh and seawater, we added dolomitic lime at a ratio of $1.0 \mathrm{~kg} / \mathrm{m}^{2}$, applying firstly $50 \%$ and the remainder divided into doses weekly applied during the cultivation. This water remained in these tanks at constant aeration for $24 \mathrm{~h}$, in order to volatilize chlorine and to dilute the dolomitic limestone.

The following ingredients were assessed: poultry viscera flour (PVF), cassava leaf hay (CLH), shrimp head flour (SHF), sugarcane yeast (SCY) and castor bean meal (CBM). These ingredients underwent chemical analysis referring to dry matter $(\mathrm{DM})$, mineral matter (MM), crude protein (CP) and ether extract (EE), following method described by the AOAC (2005)

Treatments consisted of a reference diet and five test diets composed of $70 \%$ of the reference diet and adding $30 \%$ of the ingredient to be tested. As shown in Table 1, the reference diet was prepared according to the method of NRC (2011) for crude protein and digestible energy, and as proposed by Tacon, Metian and Hasan (2009) for amino acids, vitamins and minerals. The chemical indicator, chromium oxide $\left(\mathrm{Cr}_{2} \mathrm{O}_{3}\right)$, was added to the feed at a concentration of $1 \%$, as described by Rostagno and Sakomura (2007). The ingredients were homogenized, wetted with water at $70{ }^{\circ} \mathrm{C}$, pelleted by meat grinder and placed on trays for drying in an oven at $55 \pm 5^{\circ} \mathrm{C}$ until constant weight.

Table 1. Percent composition of the reference diet used in digestibility trial for shrimps of the L. vannamei species.

\begin{tabular}{lc}
\hline \multicolumn{1}{c}{ Ingredients } & Reference diet (\%) \\
\hline Fishmeal & 35.0 \\
Soybean meal & 28.5 \\
Wheat flour & 32.2 \\
Soya oil & 2.20 \\
Premix (min + vit) ${ }^{1}$ & 1.55 \\
Common salt & 0.50 \\
BHT $^{2}$ & 0.05 \\
\hline Total & 100 \\
\hline & \\
\hline Crude protein (\%) & Analyzed and calculated values \\
Shrimp digestible energy (kcal/kg) & $34.63 *$ \\
Ether extract (\%) & 4534 \\
Crude fiber (\%) & $4.50^{*}$ \\
Calcium (\%) & 1.66 \\
Total phosphorus (\%) & 1.69 \\
Total arginine (\%) & 1.02 \\
Total lysine (\%) & 2.28 \\
Total Met + Cystine (\%) & 2.08 \\
Total threonine (\%) & 1.29 \\
\hline
\end{tabular}

${ }^{1}$ Folic acid $(\mathrm{min}) 500 \mathrm{mg} / \mathrm{kg}$. Pantothenic acid $(\mathrm{min}) 6,500 \mathrm{mg} / \mathrm{kg}$. B.H.T (min) 5,000 mg/ kg. Biotin (min) 21 $\mathrm{mg} / \mathrm{kg}$. Copper (min) $1,000 \mathrm{mg} / \mathrm{kg}$. Choline (min) $140 \mathrm{~g} / \mathrm{kg}$. Iron (min) $1,000 \mathrm{mg} / \mathrm{kg}$. Iodine (min) $50 \mathrm{mg} / \mathrm{kg}$. Manganese (min) $5,000 \mathrm{mg} / \mathrm{kg}$. Niacin $(\min ) 10 \mathrm{~g} / \mathrm{kg}$. Selenium (min) $20 \mathrm{mg} / \mathrm{kg}$. Zinc (min) $10 \mathrm{~g} / \mathrm{kg}$. Vitamin A (min) 500,000 IU/ kg. Vitamin $B_{1}(\min ) 2,600 \mathrm{mg} / \mathrm{kg}$. Vitamin $\mathrm{B}_{12}(\mathrm{~min}) 10,000 \mathrm{mcg}$. Vitamin $\mathrm{B}_{2}(\mathrm{~min}) 2,600 \mathrm{mg} /$ kg. Vitamin $B_{6}(\min ) \mathrm{mg} / \mathrm{kg}$. Vitamin $C(\min ) 40 \mathrm{~g} / \mathrm{kg}$. Vitamin $\mathrm{D}_{3}(\min ) 160,000 \mathrm{IU} / \mathrm{kg}$. Vitamin E (min) 16,000 $\mathrm{IU} / \mathrm{kg}$. Vitamin $\mathrm{K}_{3}(\mathrm{~min}) 1,000 \mathrm{mg} / \mathrm{kg} .{ }^{2} \mathrm{BHT}=$ Butylated hydroxy toluene.* Assessed values. 
Before the experiment start, the shrimps, with mean weight of $8 \mathrm{~g}$, were kept in $200-\mathrm{L}$ hatchery tanks for seven days for acclimatization, at a stocking density of 30 animals / tank. Feeding was conducted up to apparent satiation, being carried three times a day at $08 \mathrm{am}, 2 \mathrm{pm}$ and $6 \mathrm{pm}$, throughout fifteen days.

Droppings were removed via container attached to the bottom tank, three times a day, and prior to feeding. The excreta were cleaned and oven dried at $55{ }^{\circ} \mathrm{C}$ for 24 hours, then placed in freezer $\left(-100{ }^{\circ} \mathrm{C}\right)$ until chemical analyzes were done. The material was removed from the freezer and subjected to dehydration by lyophilization, to obtain constant weight. The dried feces were ground and then submitted to chemical analyzes by the method of AOAC (2005).

Apparent digestibility coefficients (ADC) of the diets were estimated as follows (Nose, 1966):

$\operatorname{ADC}(\%)=100-\left[100 \times\left(\% \mathrm{Cr}_{2} \mathrm{O}_{3} \mathrm{~d} / \% \mathrm{Cr}_{2} \mathrm{O}_{3} \mathrm{f}\right) .(\% \mathrm{Nf} / \%\right.$ $\mathrm{Nd})$ ]

In which:

$\mathrm{ADC}=$ Apparent Digestibility Coefficient (\%);

$\% \mathrm{Cr}_{2} \mathrm{O}_{3} \mathrm{~d}=$ Chromic oxide rate in the diet;

$\% \mathrm{Cr}_{2} \mathrm{O}_{3} \mathrm{f}=$ Chromic oxide rate in the feces;

$\% \mathrm{Nf}=$ Percentage of energy, protein, dry matter or ether extract in the feces;

$\% \mathrm{Nd}=$ Percentage of energy, protein, dry matter or ether extract in the diet.

Apparent digestibility of nutrients (ADn) was calculated using the formula described by Reightet, Braden and Craig (1990):

$\operatorname{ADN}(\%)=(100 / 30) \times[A D C$ test $-(70 / 100 \times$ $\mathrm{ADC}$ reference)]
In which:

ADC test $=$ Apparent Digestibility coefficient of the test diet nutrients;

ADC reference $=$ Apparent Digestibility coefficient of the reference diet nutrients.

Concentrations of chromium oxide in excreta and feedstuffs were analyzed at the Laboratory of Food Physical and Chemical Analyses of the Universidade Federal de Viçosa - UFV, using the acid digestion method proposed by Furukawa and Tsukahara (1966).

Gross energy, crude protein, dry matter, ether extract as well as digestible protein and energy were analyzed by the GLM procedure (General Linear Models). Additivity was tested by covariance analysis of the squared predicted values. Data normality was checked by an univariate procedure through W statistics (Shapiro-Wilk). In addition, variance homogeneity was evaluated by the Bartlett's test and differences were detected by the Tukey's test at 5\% probability, using the SAS statistical software version 9.1 (SAS, 1999).

\section{RESULTS AND DISCUSSION}

There was no significant difference $(p>0.05)$ among treatments regarding the values found for water quality. According to Lourenço et al. (2009), these values are adequate for shrimp of the $L$. vannamei species.

Table 2 displays the percent composition of the assessed nutrients (DM, CP, EE and MM) and gross energy of the feedstuffs.

Table 2. Chemical composition (in natural matter) of the testing ingredients.

\begin{tabular}{|c|c|c|c|c|c|}
\hline Ingredient & $\mathrm{DM}(\mathrm{g} / \mathrm{kg})$ & CP (g/kg) & MM (g/kg) & $\begin{array}{c}\mathrm{EE} \\
(\mathrm{g} / \mathrm{kg})\end{array}$ & GE (kcal/kg) \\
\hline PVF & 95.79 & 55.35 & 10.43 & 19.08 & 5,283 \\
\hline CLH & 93.66 & 22.81 & 6.17 & 5.76 & 4,800 \\
\hline SHF & 91.27 & 55.92 & 14.03 & 7.24 & 4,316 \\
\hline SCY & 89.18 & 30.29 & 13.76 & 0.69 & 3,883 \\
\hline CBM & 92.11 & 30.13 & 6.19 & 7.56 & 4,880 \\
\hline
\end{tabular}

$\mathrm{PVF}=$ poultry viscera flour; $\mathrm{CLH}=$ cassava leaf hay; $\mathrm{SHF}=$ shrimp head flour; $\mathrm{SCY}=$ sugarcane yeast; $\mathrm{CBM}=$ castor bean meal; $\mathrm{DM}=$ dry matter; $\mathrm{CP}=$ crude protein; $\mathrm{MM}=$ mineral matter; $\mathrm{EE}=$ ether extract; $\mathrm{GE}=$ gross energy.

There was significant difference between all apparent digestibility coefficients, digestible energy and digestible protein of the tested ingredients at 5\% probability by the Tukey's test. Table 3 displays the ADCs of the ingredients for DM, GE, CP, digestible energy and protein.

PVF had the lowest CDADM (27.44\%) among the tested ingredients, which is well below the findings of Cruz-Suárez et al. (2007) (90.8\%). However, our result corroborates that of Carvalho (2011), which showed a near value $(26.5 \%)$. These differences may be the result of different methods of PVF processing of each experiment.
According to Yang et al. (2009), the dry matter digestibility of food ingredients consumed by L. vannamei tend to decrease as the fiber content and ashes increase. The same authors report that low dry matter digestibility of a few plant products seems to be associated with carbohydrate quantity and chemical composition.

Carvalho (2011) and Cruz-Suárez et al. (2007) observed CDAGE values of PVF (46.4 and $93.3 \%$, respectively) higher than the ones found in this study $(33.10 \%)$. This difference might have been due to the lipid content (19.08\%), as seen in Table 2 . This component was higher for the PVF than for the 
C. A. R. NUNES et al.

Table 3. Apparent Digestibility coefficient (ADC) of the protein-based feedstuff for the $L$. vannamei shrimp.

\begin{tabular}{lccccccc}
\hline \multicolumn{1}{c}{ Variables } & \multicolumn{9}{c}{ Ingredient } \\
\cline { 2 - 7 } & PVF & CLH & SHF & SCY & CBM & CV(\%) & DP \\
CDADM (\%) & $27.44^{\mathrm{D}}$ & $76.26^{\mathrm{B}}$ & $77.78^{\mathrm{B}}$ & $90.10^{\mathrm{A}}$ & $69.68^{\mathrm{C}}$ & 3.84 & 22.1 \\
CDAGE (\%) & $33.10^{\mathrm{E}}$ & $51.19^{\mathrm{C}}$ & $90.70^{\mathrm{A}}$ & $78.05^{\mathrm{B}}$ & $43.65^{\mathrm{D}}$ & 2.43 & 22.2 \\
CDACP (\%) & $76.61^{\mathrm{B}}$ & $70.44^{\mathrm{C}}$ & $97.67^{\mathrm{A}}$ & $78.29^{\mathrm{B}}$ & $47.49^{\mathrm{D}}$ & 2.95 & 16.7 \\
DE(kcal/kgDM) & $1749^{\mathrm{E}}$ & $2457^{\mathrm{C}}$ & $3914^{\mathrm{A}}$ & $3030^{\mathrm{B}}$ & $2130^{\mathrm{D}}$ & 2.72 & 778.8 \\
DP (\%DM) & $42.4^{\mathrm{B}}$ & $16.09^{\mathrm{D}}$ & $54.62^{\mathrm{A}}$ & $23.71^{\mathrm{C}}$ & $14.31^{\mathrm{D}}$ & 2.94 & 16.7 \\
\hline
\end{tabular}

CDADM = Apparent Digestibility coefficient of dry matter; CDAGE = Apparent Digestibility coefficient of gross energy; $\mathrm{CDACP}=$ Apparent Digestibility coefficient of crude protein; $\mathrm{DE}=$ digestible energy; $\mathrm{DP}=$ digestible protein; $\mathrm{PVF}=$ poultry viscera flour; $\mathrm{CLH}=$ cassava leaf hay; $\mathrm{SHF}=$ shrimp head flour; $\mathrm{SCY}=$ sugarcane yeast; $\mathrm{CBM}=$ castor bean meal; Values followed by different letters in the same line show significant differences $(\mathrm{p}<0.05)$.

other assessed ingredients, and superior to the levels found by the above-cited authors $(13.15 \%$ and $12.6 \%)$.

As shrimps have a restrict capacity to digest diets high in lipids, the surplus of such element may have affected the metabolic functions of the crustacean, reducing their growth and survival (HU et al. 2008). In this sense, most complex carbohydrates and proteins are better used by shrimps as main sources of energy (OLMOS et al., 2011).

The PVF also presented a major CDACP (76.61\%), which was higher than that reported by Carvalho (2011) (27.7\%), but lower than those found by Siccard et al. (2006) and Cruz-Suárez et al. (2007) (78.7\% and 90.4\%, respectively). Our outcomes for CDACP may have followed exploitation level of the protein, which showed a DP rate of $42.4 \%$, directly influencing the coefficient above mentioned.

Several factors may affect DP such as enzyme inhibitors, improper diet and feed formulations with chemically and physically available proteins. Protein availability varies with ingredient's chemical composition, used raw material, cooking method, drying and storage, as well as the time spent in storing like drying at high temperature can reduce DP and produce anti-nutritional factors in some feed ingredients (YANG et al., 2009).

CLH showed the second highest ADC for DM $(76.26 \%)$ and the thirds for GE $(51.19 \%)$ and CP (70.44\%). Moreover, this ingredient presented the third highest value for DE $(2,457 \mathrm{kcal} / \mathrm{kg})$ and the fourth for DP $(16.09 \%)$.

By studying the digestibility of cassava byproducts in Nile tilapia, Santos et al. (2009) found inferior values for digestibility coefficient of shoot DM (65.53\%) and CP (53.00\%), however superior ones for GE (55.28\%). According to Ramos et al. (2012), the crude fiber content in CLH (24.5\%) may have contributed to the reduction in the use of this material, since the fiber interferes with the proper use of the energy of nutrients.

Cassava shoot has also antinutritional factors such as linamarin, which is a protease and polyphenol inhibitor, forming most stable compounds and interfering with the content of extractable and digestible proteins. Protease inhibitors are related to the defense mechanism of plants and are capable of inhibiting enzymes such as trypsin, chymotrypsin and carboxypeptidase, reducing the use of nutrients by the animal, and thus declining their development (TRAN et al., 2011).

Nutritional and antinutritional factors of plants may be influenced by harvest time, weather, plant maturity and soil fertility. By eliminating antinutritional factors, ingredients may have their quality enhanced; thus, certain elements as temperature and time become essential to the final product quality. Nevertheless, shrimp diets should be based on food with proteins of high biological value upon dehydration that removes toxic agents.

SHF presented a CDADM of $77.78 \%$, which is lower than that found by Terrazas-Fierro et al. (2010) (84.0\%), but higher than that found by Akiyama et al. (1989) (56.8\%). Such differences have relationship with ingredient quality and processing methods, which have varying times and temperatures of preparation. It can also be related to the species used and excess of other parts such as shrimp shell in the feedstock. In contrast, CDACP $(97.67 \%)$ corroborates the results of Terrazas-Fierro et al. (2010) (98.0\%), and higher than those found by Akiyama et al. (1989) (74.6\%) and Mu et al. (2000) $(88.2 \%)$, which may have been influenced by the ability of crustaceans to better use the protein of the soluble carbohydrates (ROSAS et al., 2002).

Shrimps are omnivores and scavengers, i.e. consume shells of other dead shrimp; thereby ingest sources of chitin, which in turn has nitrogen in its composition. SHF is rich in chitin, a carbohydrate that serves as an energy source for shrimp and is fundamental to better protein exploitation and thus contribute to the growth of these animals (LEI; HSIEH; CHEN, 1989).

SCY had an ADC for DM of $90.10 \%$, GE of $78.05 \%$ and CP of $78.29 \%$, being the highest for DM, and the second highest for GE and CP. This product also presented the second highest value of DE $(3,030 \mathrm{kcal} / \mathrm{kg})$, behind only of SHF $(3,914 \mathrm{kcal} /$ $\mathrm{kg}$ ) and with the third major value for DP (23.71\%).

Hisano et al. (2008) made a digestibility research using autolyzed sugarcane yeast in Nile tilapias; the results showed lower values of DM 
$(85.9 \%)$ and CP (72.2\%) and higher ones of GE $(78.05 \%)$ when compared to the results of our study.

Whole SKY has intact cell wall, rich in heteropolysaccharides structured in complex carbohydrates and proteins, such as mannoproteins and glucan, which may compromise the use efficiency, as well as other nutrients (HISANO et al., 2007).

Studies carried out by Hisano et al. (2008), testing the cell wall of sugarcane yeast in Nile tilapias showed that the complex structure of carbohydrates and protein, on the one hand, compromises protein use, however, on the other hand, improves the ADC of DM and GE.

Therefore, processes that aim at best use of SKY are needed, e.g. autolysis that improves the feed use efficiency. This ingredient also provides a good source of essential amino acids, but has some factors that affect its use in animal feed; such factors are non-protein nitrogen content and the cell wall, leading to an overestimation of the protein content within it.

ADCs found for CBM were $69.68 \%, 43.65 \%$, $47.49 \%$ and $63.97 \%$ of DM, GE, CP and EE. These represented the third highest for DM and the fourth largest value for $\mathrm{GE}$ and $\mathrm{CP}$. The material also showed an DE $(2,130 \mathrm{kcal} / \mathrm{kg})$ higher than the PVF one $(1,749 \mathrm{kcal} / \mathrm{kg})$, but the use of protein was the lowest among all materials (23.71\%).

The results for CBM can be explained because of the presence of ricin, ricinine and albumins, which are allergenic factors that cause red cell agglutination, arousing cell death by inhibiting protein synthesis (BUENO et al., 2014). This way, food processing is required for inactivation of these factors and production of a most suitable meal for animal consumption.

Unfortunately, processes to reduce antinutritional factors can reduce the protein levels, increasing deficiencies on essential amino acids as lysine, tryptophan and histidine. This problem would be a result of leaching and possible vaporization of nitrogen substances during the processing (AKANDE; ODUNSI, 2012). Moreover, the castor bean energy may decrease depending on the exposure time under treatment. This may be because part of the soluble portion of nutrients is lost to the fluid during immersion in water and fermentation caustic soda (ANNONGU; JOSÉ, 2008). In addition, there are several detoxification methods of castor bean byproducts which associated to their nutritional value make these ingredients potentially good for shrimp food.

$\mathrm{DE}$ values of the ingredients are related to the ADCs (DM, GE, CP and EE). SHF had the best result of DE $(3,914 \mathrm{kcal} / \mathrm{kg} / \mathrm{DM})$ due to factors such as increased exploitation by shrimps when using protein-derived energy and as function of apparent digestibility of DM (77.78\%), GE (90.70\%) and EE (93.97\%).
Similarly, though in reverse, PVF showed an DE with the lowest value $(1,749 \mathrm{kcal} / \mathrm{kg} / \mathrm{DM})$ and CDAGE (33.10) also lower, even though the higher gross energy $(5,283 \mathrm{kcal} / \mathrm{kg})$, second best CDACP (76 , 61\%) and CADEE (73.21\%) among all ingredients. These results indicate that shrimps could not exploit the nutrients and hence had a lower energy use of PVF.

DE data of the ingredients may have been influenced by high contents of fat in diets and respective lipid profiles. In this case, saturated and monounsaturated fatty acids can be bioconverted from enzymatic action, producing some nutritional value that is inherent in their source. According to studies of Oujifard et al. (2012), the best nutritional results were obtained with lipids from marine animals and the requirement of polyunsaturated fatty acids should achieve a certain appropriate ratio with the fatty acids in the diet.

\section{CONCLUSION}

Shrimp head flour and sugarcane yeast were the ingredients that showed the best apparent digestibility coefficients among all nutrients tested and also the digestible energy for shrimp of the $L$. vannamei species. New researches should be performed in order to improve the nutritional analysis of the five tested ingredients.

\section{ACKNOWLEDGEMENTS}

The authors want to thank the $\mathrm{CNPq}$ for granting scholarship and reserve funds; we also would like to thank the companies Bahia Pesca, Guaraves Alimentos, Rações Primor, Pratigi Alimentos for providing inputs and biological material; and finally to the Universidade Federal do Recôncavo da Bahia (Federal University of Bahia Reconcavo) for experimental facilities and staff.

\section{REFERENCES}

AKANDE, T.; ODUNSI, A. A. Nutritive value and biochemical changes in broiler chickens fed detoxified castor kernel cake based diets. Africam jornal of biotechnology, Lagos, v. 11, n. 12, p. 2904 $-2911,2012$.

AKIYAMA, D. M. et al. Apparent digestibility of feedstuffs by the marine shrimp Penaeus vannamei BOONE. Nippon Suisan Gakkaishi, Tokyo, v. 55, n. 1, p. 91-98, 1989.

ANNONGU A. A.; JOSEPH J. K. Proximate analysis of castor seeds and cake. Journal of 
Applied Sciences and Environmental Management, Toronto, v. 12, n. 1, p. 39- 41, 2008.

AOAC. Official methods of analysis of the Association Analytical Chemists. 18. ed. Gaithersburg, Maryland, 2005.

ASSIS, A. S.; STAMFORD, T. C. M.; STAMFORD, T. L. M. Bioconversão de resíduos de camarão Litopenaeus vannamei (Booner, 1931) para produção de biofilme de quitosana. Revista Iberoamericana de Polímeros, Logroño, v. 9, n. 8, p. $480-499,2008$.

BHASKAR, $N$. et al. Yield and chemical composition of fractions from fermented shrimp biowaste. Waste Management \& Research, Nassaulaan, v. 28, n. 1, p. 64-70, 2010.

BUENO, C. F. D. et al. Torta de mamona destoxificada para alimentação de poedeiras comerciais. Ciência Rural, Santa Maria, v. 44, n. 3, p. 538-543, 2014.

BUGLIONE?NETO, C. et al. Métodos para determinação da digestibilidade aparente de dietas para camarão marinho suplementadas com probiótico. Pesquisa agropecuária brasileira, Brasília, v. 48, n. 8, p. 1021-1027, 2013.

CARVALHO, R. A. P. L. F. Desenvolvimento de um sistema de recirculação para estudos sobre digestibilidade em condições de alto desempenho para camarões marinhos: Avaliação de ingredientes proteicos alternativos à farinha de peixe em diferentes níveis de inclusão em dietas para juvenis de Litopenaeus vannamei. 2011. 267 f. Tese (Doutorado em Ciências: Área de Concentração em Oceanografia Biológica) Universidade de São Paulo, São Paulo, 2011.

CRUZ-SUÁREZ, L. E. et al. Replacement of fish meal with poultry by-product meal in practical diets for Litopenaeus vannamei, and digestibility of the tested ingredients and diets. Aquaculture, Amsterdam, v. 272, n. 1-4, p. 466-476, 2007.

CUMMINS,V. C. et al. Replacement of fish meal with soybean meal, alone or in combination with distiller's dried grains with solubles in practical diets for pacific white shrimp, Litopenaeus vannamei, Grown in a Clear-Water Culture System. Journal of the world aquaculture society, Baton Rouge, v. 44, n. 6, p. $775-785,2013$.

DA, C. T.; LUNDH, T.; LINDBERG, J. E. Evaluation of local feed resources as alternatives to fish meal in terms of growth performance, feed utilisation and biological indices of striped catfish (Pangasianodon hypophthalmus) fingerlings.
Aquaculture, Amsterdam, v. 364-365, n. 1, p. 150 $156,2012$.

DASTIDAR, P. G.; MALLIK, A.; MANDAL, N. Contribution of shrimp disease research to the development of the shrimp aquaculture industry:an analysis of the research and innovation structure across the countries. Scientometrics, Budapest, v. 97, n. 1, p. 659-674, 2013.

GOLTERMAN, H. L.; CLYMO, R. S; OHNSTAD, M. A. M. Methods for physical and chemical analisis of freshwaters, London: Blakwell Science Publication, 1978, $214 \mathrm{p}$.

GHUO, R. et al. Effect of dietary cornstarch levels on growth performance, digestibility and microscopic structure in the white shrimp, Litopenaeus vannamei reared in brackish water. Aquaculture Nutrition, Oxford, v. 12, n. 1, p. 83$88,2006$.

HAVIRD, J. C.; SANTOS, S. R.; HENRY, R. P. Osmoregulation in the Hawaiian anchialine shrimp Halocaridina rubra (Crustacea: Atyidae): expression of ion transporters, mitochondria-rich cell proliferation and hemolymph osmolality during salinity transfers. The Journal of Experimental Biology, Cambridge, v. 217, n. 1, p. 2309-2320, 2014

HISANO, H. et al. Composição nutricional e digestibilidade aparente da levedura íntegra, da levedura autolisada e da parede celular pela tilápiado-Nilo. Ciência Animal Brasileira, Goiânia, v. 9, n. 1, p. 43-49, 2008.

HISANO, $\mathrm{H}$. et al. Desempenho produtivo de alevinos de tilápia-do-nilo alimentados com levedura e derivados. Pesquisa Agropecuária Brasileira, Brasília, v. 42, n. 7, p. 1035-1042, 2007.

HU, Y. et al. Growth and body composition of juvenile white shrimp, Litopenaeus vannamei, fed different ratios of dietary protein to energy. Aquaculture Nutrition, Oxford, v. 14, n. 6, p. 499 506, 2008.

LEI, C. H.; HSIEH, L. Y.; CHEN, C. K. Effects of salinity on the oxygen consumption and ammonia-N excretion of young juvenile of the grass shrimp, Penaeusmonodon Fabricius. Bulletin of the Institute of Zoology, Academia Sinica, Taipei, v. 28 , n. 1, p. 245-256, 1989

LEMOS, D.; LAWRENCE, A. L.; SICCARDI III, A. J. Prediction of apparent protein digestibility of ingredients and diets by in vitro $\mathrm{pH}$ ? $\mathrm{stat}$ degree of protein hydrolysis with species? juvenile Pacific white shrimp Litopenaeus vannamei. 
Aquaculture, Amsterdam, v. 295, n. 1, p. 89-98, 2009.

LIMA, S. B. P. et al. Valor nutricional da farinha de cabeça do camarão marinho Litopenaeus vannamei para frangos de corte. Revista Caatinga, Mossoró, v. 20, n. 3, p. 38-41, 2007.

LIN, H.Z. et al. Effect of dietary traditional Chinese medicines on apparent digestibility coefficients of nutrients for white shrimp Litopenaeus vannamei, Boone. Aquaculture, Amsterdam, v. 253, n. 1-4, p. 495-501, 2006.

LOURENÇO, J. A. et al. Influência de diferentes dietas no desenvolvimento do camarão Litope-naeus vannamei (Boone, 1931) em berçários intensivos. Acta Scientiarum. Biological Sciences, Maringá, v. 31, n. 1, p. 1-7, 2009.

MOTA, C. J. A.; PESTANA, C. F. M. Co-produtos da Produção de Biodiesel. Revista Virtual de Quimica, Niterói, v. 3, n. 5, p. 416-425, 2011.

MU, Y. Y. et al. Protein digestibility and amino acid availability of several protein sources for juvenile Chinese hairy crab Eriocheirsinensis H. MilneEdwards (Decapoda, Grapsidae). Aquaculture Research, Oxford, v. 31, n. 10, p. 757-765, 2000.

NATIONAL RESEARCH COUNCIL (NRC): Nutrient requirements of fish and shrimp. National Academy Press, Washington, DC, 2011, $432 \mathrm{p}$.

NOSE, T. Recents advances in the study of fish digestion in Japan. In: SYMPOSIUM ON FEEDING TROUT AND SALMON CULTURE, SC II7., 1966, Belgrade. Anais... Belgrade: EIFAC, 1966. p. 17.

OLMOS, J. et al. Funcional feed assessment on Litopenaus vannamei using $100 \%$ fish meal replacement by soybean meal, high levels of complex carbohydrates and bacillus probiotic strains. Marine Drugs, Basileia, v. 6, n. 6, p. 1119 - 1132, 2011.

OUJIFARD, A. et al. Growth and apparent digestibility of nutrients, fatty acids and amino acids in Pacific white shrimp, Litopenaeus vannamei, fed diets with rice protein concentrate as total and partial replacement of fish meal. Aquaculture, Amsterdam, v. 342-343, n. 1, p. 56-61, 2012.

POVEDA-PARRA, A. R. et al. Levedura de cana-de -açúcar spray dry na alimentação de suínos na fase de crescimento e terminação. Arquivo Brasileiro de Medicina Veterinária e Zootecnia, Belo Horizonte, v. 65, n. 1, p. 221-230, 2013.
PRAPAIWONG, N.; BOYD, C. E. Trace elements in waters of inland, low-salinity shrimp ponds in Alabama. Aquaculture Research, Oxford, v. 45, n. 2, p. 327-333, 2014.

RAMOS, A. P. S. et al. Digestibility of agroindustrial byproducts in 200 and 300-g Nile tilapia. Revista Brasileira de Zootecnia, Viçosa, v. 41, n. 2, p.4 62-466, 2012.

REIGHT, R. C.; BRADEN, S. L.; CRAIG, R. J. Apparent digestibility coefficients for common feedstuffs in formulated diets for red swamp crayfish, Procambarus clrkii. Aquaculture, Amsterdam, v. 84, n. 3-4, p. 321-334, 1990.

ROSAS, C. et al. An energetic and conceptual model of the physiological role of dietary carbohydrates and salinity on Litopenaeus vannamei juveniles. Journal Experimental Marine Biology, Christchurch, v. 268, n. 1, p. 47-67, 2002.

SAKOMURA, N. K.; ROSTAGNO, H. S. Métodos de pesquisa em nutrição de monogástricos. Jaboticabal, SP: FUNEP, 2007. 283 p.

SANTOS, E. L. et al. Digestibilidade de subprodutos da mandioca para a Tilápia do Nilo. Revista Brasileira de Ciências Agrárias, Recife, v. 4, n. 3, p. 358-362, 2009.

SAS. SAS Software.Version 9.1. Cary, North Carolina: SAS Institute Inc., 1999.

SICCARDI, A. J. et al. Digestibilidad aparente de energia, proteína y material seca de ingredientes utilizados em alimentos balanceados para El camarón Blanco Del pacifico Litopenaeus vannamei. In: VIII SIMPOSIUM INTERNACIONAL DE NUTRICION ACUÍCOLA, 2006, Monterrey. Anais... Monterrey: Universidad Autónoma de Nuevo León, 2006. p. 213-237.

TACON, A. G. J., METIAN, M., HASAN, M. R. Feed ingredients and fertilizers for farmed aquatic animals sources and composition. Roma: Fisheries and Aquaculture Technical, FAO, 2009. n. 540, 209p. Disponível em: <http://www.fao.org/ docrep/012/i1142e/i1142e00.htm $>$.Acesso em:10 marc. 2013

TERRAZAS-FIERRO, M. M. et al. Apparent digestibility of dry matter, protein, and essential amino acid in marine feedstuffs for juvenile whiteleg shrimp Litopenaeus vannamei. Aquaculture, Amsterdam, v. 308, n. 1, p. 166-173, 2010.

TRAM, N. D. Q. et al. A comparative study on the apparent digestibility of selected feedstuffs in hybrid catfish (Clarias macrocephalus $\times$ Clarias 
gariepinus) and Nile tilapia (Oreochromis niloticus). Aquaculture Nutrition, Oxford, v. 17, n. 2, p. 636643, 2011.

YANG, Q. et al. Apparent digestibility of selected feed ingredients for white shrimp Litopenaeus vannamei, Boone. Aquacultu re Research, Oxford, v. 41, n. 1, p. 78-86, 2009 